\title{
HEAVY METALS IN CULTIVATED SOIL AND PLANTS OF DAMOUR URBAN AREA - LEBANON
}

\author{
Fadel D. ${ }^{1}$, Argyraki A. ${ }^{2}$, Papageorgiou S. ${ }^{2}$ and Kelepertzis E. ${ }^{2}$ \\ ${ }^{1}$ Lebanese University, Facutly of Agriculture, Department of Plant Production. Dekwaneh- \\ Lebanon,dr.danifadel@gmail.com \\ ${ }^{2}$ National \& Kapodistrian University of Athens, Faculty of Geology \& Geoenvironment, \\ Panepistimiopolis Zographou, 15784, Athens, Greece, argyraki@geol.uoa.gr, \\ papagstamatia@hotmail.com,kelepert@geol.uoa.gr
}

\begin{abstract}
Preliminary data on heavy metals concentrations in soil and edible plants of DamourLebanon are presented for the first time. Concentration ranges of $\mathrm{Zn}, \mathrm{Cu}, \mathrm{Ni}, \mathrm{Cr}, \mathrm{Co}$, $\mathrm{Mn}, \mathrm{Fe}, \mathrm{Ba}, \mathrm{Pb}$ and $\mathrm{Cd}$ in soils and vegetables collected from urban allotments in Damour were determined and assessed taking into account the pseudototal (extracted by aqua regia) and mobilizable ( $0.43 \mathrm{M}$ acetic acid extractable) concentrations of the elements in the rhizosphere soil of the plants as well as the total concentrations in edible plant tissue. Average elemental concentrations in urban allotments are low in general. No detectable concentrations of the non-essential heavy metals $\mathrm{Pb}$ and As were measured in the studied plants while concentrations of micronutrient elements in plants were within normal ranges. The collected data indicate that previous land use is an important factor controlling heavy metal content in soil and that there is a complex mechanism controlling micronutrient uptake by plants.

Keywords: vegetables, harmful elements, mobility, phytoavailability.
\end{abstract}

\section{Пєрі́ $\eta \psi \eta$}

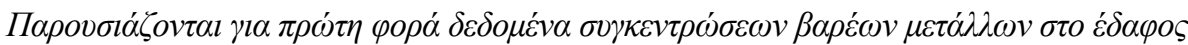

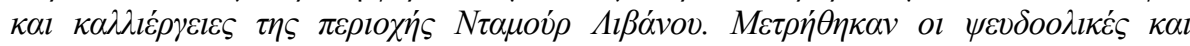

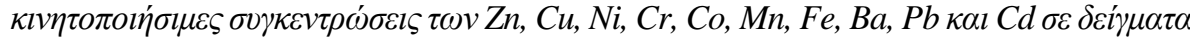

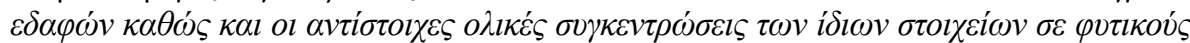

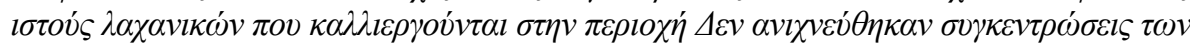

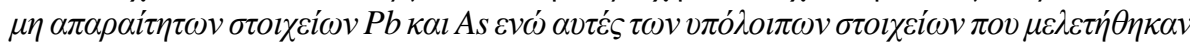

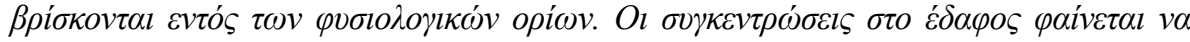

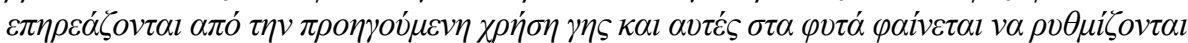

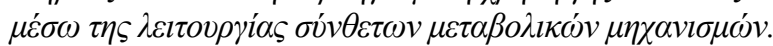

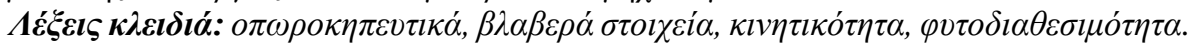

\section{Introduction}

Heavy metals are among the most common chemical constituents in soil that are associated with human activities (Rodríguez Martín et al., 2015; Tahmasbian et al., 2013). Some of these potentially harmful elements, such as zinc $(\mathrm{Zn})$, copper $(\mathrm{Cu})$, manganese $(\mathrm{Mn})$, chromium $(\mathrm{Cr})$, nickel $(\mathrm{Ni})$ and cobalt (Co), are known as essential trace metals because they are required only in minute amounts by living 
organisms for normal growth while others such as lead $(\mathrm{Pb})$, arsenic $(\mathrm{As})$ and cadmium $(\mathrm{Cd})$ are toxic even at low concentrations (Kelepertzis and Argyraki, 2015). Bioavailability of heavy metals in soils is critically dependent on the chemical speciation of the metals and plants respond only to the fraction that is "phytoavailable" (Yao-Tsung et al., 2014). The readily soluble fraction of heavy metals in soil is generally considered to be phytoavailable, but there is growing awareness that the various methods for assessment of "soluble" and "phytoavailable" fractions need reevaluation. It is generally known that there are variations in the rates of soil to plant transfer between different plant species but also between the same plant species from different areas (McLaughlin and Singh, 1999). It has been reported that previous land uses of the cultivated areas have a significant contribution to the levels of heavy metal contamination of soil and plants (Srour, 2000).

The Lebanese National Center for Scientific Research (2006) published "the soil map of Lebanon" and the most widely represented soils reported, were calcareous Terra-Rossa and Rendzina soils located in the agricultural plains of Bekaa, Aakkar, Koura, Sour, Saida, Rachaya and Hasbaya while outcropping rocks include sandstone, basalt and similar older volcanic material. Most of Lebanese soils are high in active clays with the exception of some marly and sandy soils. Active clays are clays with the ability to adsorb and immobilize positively charged ions, namely heavy metals. Earlier studies with reference to the dynamics of some heavy metals $(\mathrm{Cd}, \mathrm{Ni}$, and $\mathrm{Cr}$ ) in four Lebanese soils (Samad, 2000) and effect of acidifying fertilizers on $\mathrm{Cd}, \mathrm{Cr}$ and $\mathrm{Ni}$ mobility and uptake by radish plants grown on four different Lebanese soils (Srour, 2000) were published. In 2008, Darwish analyzed the soil-groundwater vulnerability to contamination by heavy metals in the central Bekaa plain. Generally, soils in Lebanon are young and characterized by fragility, poor consistency and shallowness, especially on sloping terrains. A few publications exist on the soil database and mapping (Darwish et al., 1999; Samad, 2000); however, there are no published data related to the specific area of Damour, south of Beirut. This study is the first to present preliminary data on the interaction between soil and edible plants with respect to heavy metal concentrations in Damour, Lebanon. The main objectives were to determine the concentration range of heavy metals $(\mathrm{Zn}, \mathrm{Cu}$, $\mathrm{Ni}, \mathrm{Cr}, \mathrm{Co}, \mathrm{Mn}, \mathrm{Fe}, \mathrm{Ba}, \mathrm{Pb}$ and $\mathrm{Cd}$ ) in 16 samples of the edible parts of cultivated plants collected from urban allotments in Damour, and to assess the pseudototal and mobilizable concentrations of the same elements in the rhizosphere soil of the collected plants.

\section{Materials and Methods}

\subsection{Description of the study area}

The study area is located in Damour, a Lebanese town $24 \mathrm{~km}$ south of central Beirut, and a part of Greater Beirut (Fig. 1). The region has a Mediterranean climate with intensive precipitation between January and May (600-900 mm). The city is located in one of the few flat areas of the Lebanese coast. It is built to the north of the river, the ancient Tamyrus. This region of the southern coastal hills is a typical horticultural area, with large-scale greenhouse production of many fruits and vegetables. The pilot study area pulls water exclusively from groundwater wells due to the absence of any collective irrigation network.

Since this area is located in the central part of Lebanon, it is characterised by the intimate contact between the mountain and the sea, as well as the quasi absence of the coastal plain (Sanlaville, 1977). Concerning the pedology of the area around Damour, the karstic parent rock is covered by red soils "Terra Rossa" (El Moujabber et al., 2005; Darwish and Zurayk, 1997). Red soils are consisted of residual clay after calcareous material loss that can facilitate water intrusion. The northern part of Damour (Hadeth-Choueifat) consists of large patches of gravely sandy soils. Those soft fluvial deposits belong to the Quaternary and enhance horizontal water infiltration. The southern part of Damour belongs to the Cenomanian-Turanian (C4-5) karstified hard limestone (Dubertret, 1955) which is susceptible to seawater intrusion (FAO, 1973). The rock mineralogy is simple including calcite. Metallic minerals appear to be confined to the iron ores of haematite and limonite (Walley, 
1998). No data exist on the pollution status of Damour as the area is not included in the Lebanese pollutant release and transfer register (El-Jisr, 2014).

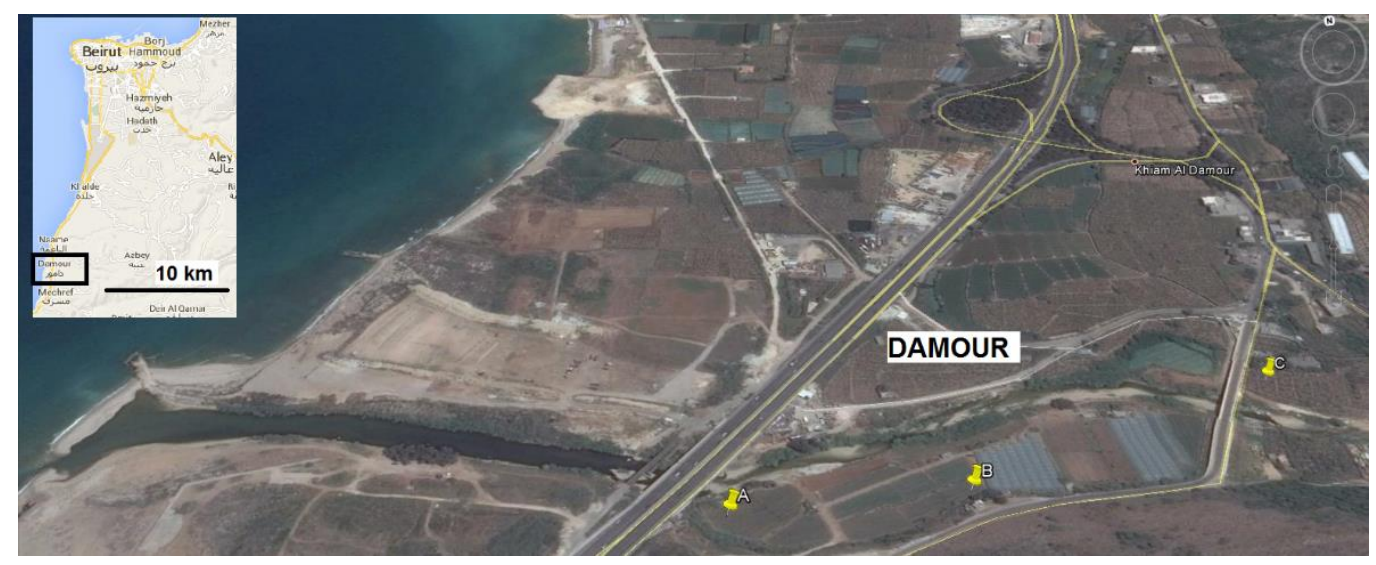

Figure 1 - Air photograph of the study area showing the location of sampled allotments (A, B, C).

\subsection{Sampling methodology and preparation for analyses}

Soil and plant samples were collected in the spring of 2015 from several urban allotments in the city of Damour, Lebanon. The samples were collected from three communal allotments within Damour: site A, site B and site C (Fig. 1). The distance between them is a few hundred meters. Sixteen different plant species were selected for plant sampling and each one was accompanied by its rhizosphere soil sample (depth 0-10 cm). After collection the soil samples were air dried at a constant temperature of $40{ }^{\circ} \mathrm{C}$ for 3 days in a thermostatically controlled oven at the Laboratory of Soil Sciences in the Faculty of Agriculture of the Lebanese University. The soil was subsequently sieved using a $2 \mathrm{~mm}$ nylon sieve. Also, the edible parts of plants were selected, thoroughly washed three times with deionized water and air dried at room temperature. All dried samples were stored in plastic bags at room temperature in a dark room for transportation. Soil and relevant plant samples were finely ground using automated agate mill for further analyses in the Laboratory of Economic Geology and Geochemistry in the National and Kapodistrian University of Athens. The total concentrations of heavy metals $(\mathrm{Pb}, \mathrm{Zn}, \mathrm{Cu}, \mathrm{Mn}, \mathrm{Cr}, \mathrm{Ni}, \mathrm{Co}, \mathrm{Cd})$ and of trace elements $(\mathrm{Fe}, \mathrm{Ba})$ in plants were measured by Inductively Coupled Plasma Optical Emission Spectroscopy (ICP-OES) following microwave digestion by $\mathrm{HNO}_{3} / \mathrm{H}_{2} \mathrm{O}_{2}, 6: 1 \mathrm{v} / \mathrm{v}$. Pseudototal heavy metal concentrations in soil were measured by ICP-OES following digestion by a mixture of $\mathrm{HNO}_{3}, \mathrm{H}_{2} \mathrm{O}_{2}$ and $\mathrm{HCl}$ (USEPA, 2002). Also, acetic acid (0.43 M) extractable concentrations of same heavy metals and trace elements were measured by the same analytical technique after mixing $1 \mathrm{~g}$ of each soil sample with $40 \mathrm{ml}$ acetic acid and shaking for $16 \mathrm{~h}$ at room temperature in an overhead shaker. All used utensils were thoroughly washed between the samples to avoid any cross contamination. Analytical quality control procedures including duplicate analysis performance, blank solutions inclusion and soil certified reference materials (NIST SRM 2709 and NIST SRM2711a for the total analysis and BCR483 and BCR-484 for the acetic acid extraction) were performed at random positions within the analytical batches. The obtained results from analytical control were found within acceptable limits for all geochemical results.

\subsection{Assessment of physicochemical soil parameters}

The major physicochemical properties of topsoil were measured including $\mathrm{pH}$, organic matter content and texture (sand, silt, clay). Soil pH was measured after mixing the sieved soil samples $(<2$ $\mathrm{mm}$ ) with deionized water in a solid -to-liquid ratio of 1:2.5 (ISO, 1994). Organic matter content of the soil samples was estimated by the loss-on-ignition (LOI) method (US-EPA, 2002) by heating 1 $\mathrm{g}$ of each sample to $450^{\circ} \mathrm{C}$ for 4 hours in a furnace oven. Since the method determines the organic matter content in the soil, a conversion factor of 1.724 has been used to convert organic matter to 
organic carbon based on the assumption that organic matter contains $58 \%$ organic $\mathrm{C}$ (i.e., g organic matter/l $.724=\mathrm{g}$ organic $\mathrm{C}$ ). The grain size distribution in the sand, silt and clay fractions was determined using the Bouyoucos Hydrometer Method (Bouyoucos, 1962).

\section{Results and Discussion}

\subsection{Heavy metals in soil samples}

The measured pseudototal concentrations of heavy metals in soil (S) samples and their sampling sites (coded as A, B and C) are presented in Table 1. The statistical summary of physicochemical properties including $\mathrm{pH}$, total carbon (TOC) and texture (sand, silt, clay \%) and acetic acid extractable concentrations of heavy metals for the investigated soil samples from Damour city are shown in Table 2.

Mean values of the pseudototal elemental concentrations in soil are following the decreasing order $\mathrm{Fe}>\mathrm{Mn}>\mathrm{Cu} \sim \mathrm{Zn}>\mathrm{Ba}>\mathrm{Cr}>\mathrm{Ni}>\mathrm{Sb}$. Iron registered the highest concentration in all the extracts among the metals (Table 1). Most of soil textures shown in Table 2 are loamy sand (means of sand and clay are 81.8 and $6.3 \%$ respectively). The minimum sand percentage is 69.92 giving a sandy loam texture to soils grown with potatoes and the maximum sand percentage is 94.72 giving a sandy texture to soils grown with Armenian cucumbers. For example, potatoes grow in any of all these well drained soils. The TOC average value of $2.8 \%$ is considered normal for urban agriculture soils. However, in contrast to other studies (Rodrigues et al., 2009) no significant correlations were detected between the key soil properties and the pseudototal concentrations of heavy metals. The pH values of soil samples ranged from 7.4 (slightly alkaline) to 8.4 (moderate alkaline). The decreasing order of soil extractable concentrations differs from the order of pseudototal concentrations and is as follows: $\mathrm{Mn}>\mathrm{Ba}>\mathrm{Zn}>\mathrm{Co}>\mathrm{Fe}>\mathrm{Ni}>\mathrm{Cu}$. Manganese presents the highest extractability ratio while $\mathrm{Fe}$ is hardly extractable by the dilute acetic acid (Fig. 2). The low extractability ratio of $\mathrm{Cu}$ is also worth noting as if combined with the relatively low pseudototal concentrations in soil might be indicative of $\mathrm{Cu}$ deficiency in the plants grown in the study area.

\subsection{Heavy metals in plant samples}

The myriad of parameters controlling the chemical fate of specific elements in soils determine their solubility and availability for plant uptake. The elemental concentrations in plant tissues are presented in Table 1.

Plant tissue average content of heavy metals is generally lower than the respective content of rhizosphere soil with some exceptions in our study. The highest concentration of $\mathrm{Zn}(135 \mathrm{mg} / \mathrm{kg})$ was found in potato tubers of site A and the lowest $(16.6 \mathrm{mg} / \mathrm{kg})$ in cucumber. The rate of $\mathrm{Zn}$ absorption differs greatly among both plant species and growth media (Kabata-Pendias et al., 2001; Warren et al., 1970). The levels of $\mathrm{Cu}$ in cucumbers $(368.8$ and $359.1 \mathrm{mg} / \mathrm{kg}$ ) are also extremely high when compared to other edible plant tissues (average $46.8 \mathrm{mg} / \mathrm{kg}$ ). The levels of $\mathrm{Cu}$ in spring onion were also high $(94.4 \mathrm{mg} / \mathrm{kg})$ when compared to the normal levels recommended by WHO/FAO and NAFDAC for metals in foods and vegetables (in the order of $30 \mathrm{mg} / \mathrm{kg}$ ). High levels of $\mathrm{Cu}$ in soil have been reported by various researchers (Kakulu, 2003 and Awofolu, 2005) and may explain high concentrations in plant tissue, however, in the present study 
Table 1 - Sample codes, plant species and their respective pseudototal concentrations (mg/kg) of elements in soil (S) and plant (P) tissues.

Sampling areas are coded as (A), (B) and (C). bdl = below detection limit.

\begin{tabular}{|c|c|c|c|c|c|c|c|c|c|c|c|c|c|c|c|c|c|c|c|c|c|}
\hline 总 & $\begin{array}{c}\text { Scientific } \\
\text { name }\end{array}$ & $\begin{array}{c}\text { Common } \\
\text { name }\end{array}$ & $\stackrel{g}{\grave{2}}$ & $\begin{array}{c}\text { Zn } \\
\text { S }\end{array}$ & $\begin{array}{c}\mathbf{Z n} \\
\mathbf{P}\end{array}$ & $\begin{array}{c}\mathrm{Cu} \\
\mathrm{S}\end{array}$ & $\begin{array}{c}\mathbf{C u} \\
\mathbf{P}\end{array}$ & $\begin{array}{l}\mathrm{Ni} \\
\mathrm{S}\end{array}$ & $\begin{array}{l}\mathbf{N i} \\
\mathbf{P}\end{array}$ & $\begin{array}{c}\mathrm{Cr} \\
\mathrm{S}\end{array}$ & $\begin{array}{c}\mathrm{Cr} \\
\mathbf{P} \\
\end{array}$ & $\begin{array}{c}\text { Co } \\
\text { S }\end{array}$ & $\begin{array}{c}\text { Co } \\
\mathbf{P} \\
\end{array}$ & $\begin{array}{c}\mathrm{Sb} \\
\mathrm{S}\end{array}$ & $\begin{array}{c}\text { Sb } \\
\mathbf{P}\end{array}$ & $\begin{array}{c}\text { Mn } \\
\text { S }\end{array}$ & $\begin{array}{c}\text { Mn } \\
\mathbf{P}\end{array}$ & $\begin{array}{c}\mathrm{Fe} \\
\mathrm{S}\end{array}$ & $\begin{array}{c}\mathbf{F e} \\
\mathbf{P}\end{array}$ & $\begin{array}{c}\mathbf{B a} \\
\mathbf{S}\end{array}$ & $\begin{array}{c}\text { Ba } \\
\mathbf{P}\end{array}$ \\
\hline DS1 & Cucumis sativus & cucumber & $\mathrm{A}$ & 114 & 27.4 & 32 & 5.1 & 23 & 1.9 & 26 & bdl & 54 & 11.1 & 1.5 & 0.5 & 384 & 19.9 & 19386 & 485 & 108 & 22.2 \\
\hline DS2 & Allium сера & green onion & $\mathrm{A}$ & 119 & 25.4 & 15 & 3.2 & 21 & 13.7 & 23 & 18.5 & 51 & 94.2 & 8.4 & 0.9 & 352 & 16.3 & 18932 & 561 & 105 & 16.8 \\
\hline DS3 & Solanum tubersosum & potato & $\mathrm{A}$ & 129 & 134.8 & 16 & 17.6 & 19 & 4.4 & 21 & bdl & 63 & 17.4 & 3.2 & 0.8 & 343 & 46.4 & 17907 & 763 & 97 & 45.0 \\
\hline DS4 & Cuсurbita pepo & kousa squash & A & 59 & 47.6 & 10 & 9.2 & 21 & 5.0 & 22 & bdl & 54 & 10.4 & 0.8 & 0.6 & 367 & 39.4 & 20237 & 2153 & 69 & 26.0 \\
\hline DS6 & Brassica oleracea & cabbage & A & 62 & 73.8 & 12 & 5.2 & 44 & 4.0 & 37 & bdl & 63 & 2.2 & bdl & 0.4 & 573 & 72.6 & 1686 & 225 & 61 & 56.8 \\
\hline DS7 & Mentha spicata & spearmint & $\mathrm{A}$ & 171 & 31.0 & 22 & 7.6 & 24 & 3.8 & 25 & bdl & 55 & 6.6 & 1.1 & 0.6 & 372 & 41.6 & 20144 & 235 & 139 & 33.6 \\
\hline DS8 & Phaseolus vulgaris & common beans & A & 56 & 32.6 & 11 & 5.4 & 43 & 7.6 & 36 & bdl & 69 & 17.6 & bdl & 0.8 & 607 & 115.0 & 21754 & 2938 & 69 & 34.0 \\
\hline DS9 & Phaseolus vulgaris & white kidney beans & $\mathrm{B}$ & 63 & 41.4 & 11 & 13.8 & 22 & 6.0 & 24 & bdl & 54 & 2.2 & bdl & 0.6 & 405 & 22.0 & 8869 & 119 & 71 & 11.6 \\
\hline DS10 & Cichorium intybus & chicory & $\mathrm{B}$ & 64 & 49.4 & 13 & 7.6 & 41 & 4.2 & 36 & bdl & 68 & 5.0 & bdl & 0.4 & 552 & 78.8 & 21616 & 371 & 74 & 14.4 \\
\hline DS12 & Solanum melongena & eggpalnt & B & 74 & 21.8 & 14 & 2.6 & 23 & 4.8 & 25 & bdl & 48 & 10.0 & bdl & 0.8 & 396 & 30.0 & 20397 & 690 & 102 & 40.6 \\
\hline DS13 & Cucumis melo & armenian cucumber & $\mathrm{B}$ & 48 & 44.8 & 13 & 11.6 & 20 & 6.0 & 27 & bdl & 56 & 30.4 & 1.6 & 1.0 & 252 & 19.2 & 17110 & 423 & 105 & 13.4 \\
\hline DS14 & Solanum lycopersicum & tomato & $\mathrm{C}$ & 63 & 46.0 & 7 & 12.0 & 17 & 3.2 & 14 & bdl & 54 & 5.0 & 0.3 & 0.4 & 302 & 64.4 & 18772 & 576 & 44 & 27.8 \\
\hline DS15 & Beta vulgaris & chard & $\mathrm{C}$ & 67 & 27.0 & 16 & 6.2 & 24 & 2.8 & 26 & bdl & 52 & 8.2 & bdl & 0.8 & 392 & 121.6 & 20674 & 525 & 76 & 31.8 \\
\hline DS16 & Raphanus sativus & radish & $\mathrm{C}$ & 64 & 44.4 & 14 & 31.0 & 21 & 16.6 & 21 & 12.0 & 59 & 25.2 & 1.7 & 0.6 & 371 & 16.8 & 19724 & 934 & 78 & 12.0 \\
\hline DS17 & Abelmoschus esculentus & okra & $\mathrm{C}$ & 46 & bdl & 12 & bdl & 19 & bdl & 26 & bdl & 46 & bdl & bdl & bdl & 258 & bdl & 17203 & bdl & 111 & bdl \\
\hline DS18 & Lactuca sativa & lettuce & $\mathrm{C}$ & 59 & 29.0 & 9 & 9.0 & 21 & 3.8 & 21 & bdl & 61 & 21.2 & 1.1 & 1.0 & 354 & 72.8 & 20280 & 648 & 62 & 48.8 \\
\hline DS19 & Cucumis sativus & cucumber & $\mathrm{A}$ & 122 & 59.4 & 37 & 359.1 & 25 & 4.0 & 31 & bdl & 49 & 18.0 & bdl & 6.6 & 423 & 85.2 & 20358 & 1366 & 130 & 51.2 \\
\hline DS21 & Mentha spicata & spearmint & A & 65 & 37.0 & 13 & 2.8 & 48 & 2.0 & 46 & bdl & 72 & 7.4 & bdl & 0.6 & 605 & 21.0 & 21724 & 177 & 72 & 9.2 \\
\hline DS23 & Cucumis sativus & cucumber & $\mathrm{A}$ & 117 & 16.6 & 33 & 368.8 & 25 & 2.2 & 29 & bdl & 53 & 5.6 & bdl & 0.4 & 419 & 17.8 & 20224 & 410 & 124 & 26.8 \\
\hline DS24 & Mentha spicata & spearmint & $\mathrm{A}$ & 61 & 29.0 & 13 & 11.8 & 48 & 4.0 & 46 & bdl & 70 & 35.6 & bdl & 1.0 & 609 & 79.4 & 21740 & 790 & 73 & 61.0 \\
\hline
\end{tabular}




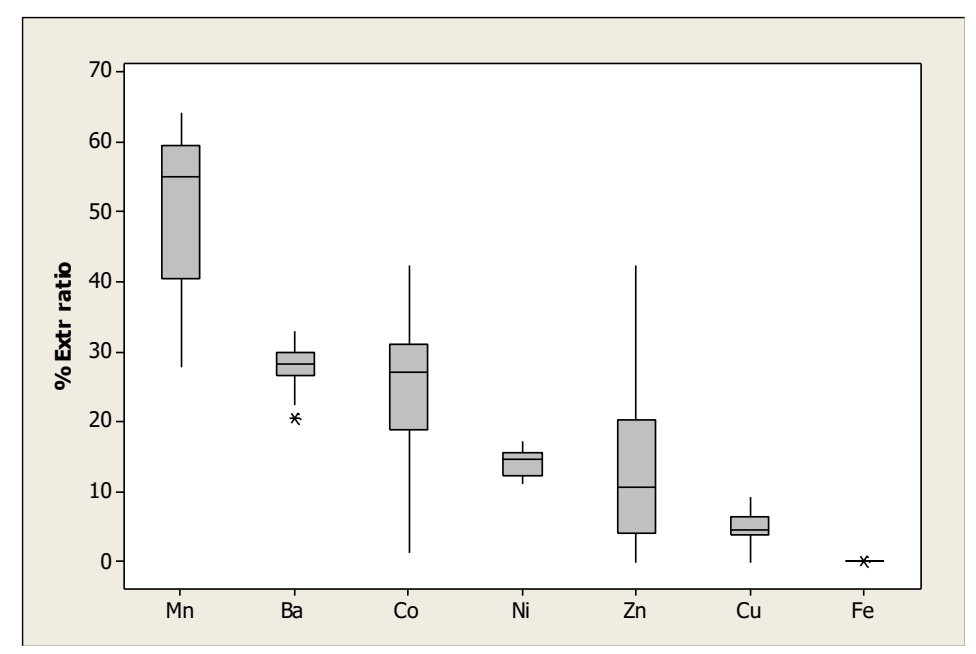

Figure 2 - Box plots of extractability ratios of the studied elements in soils of Damour, based on pseudototal and dilute acetic acid extractable concentrations. The elements are ordered according to decreasing median value (horizontal lines).

soil $\mathrm{Cu}$ is relatively low and high plant concentrations are sporadic. This is indicative of a different source of $\mathrm{Cu}$ in the specific samples, possibly related to crop management practices.

The highest concentrations of Fe were found in kousa squash $(2153 \mathrm{mg} / \mathrm{kg})$, common beans $(2938$ $\mathrm{mg} / \mathrm{kg}$ ) and cucumber $(1366 \mathrm{mg} / \mathrm{kg}$ ) grown in site A. Also, radish (934 mg/kg), spearmint (790 $\mathrm{mg} / \mathrm{kg}$ ) and lettuce $(648 \mathrm{mg} / \mathrm{kg})$ grown in site B and site C had relatively high Fe concentration compared to the normal levels recommended by WHO/FAO and NAFDAC for metals in food and vegetables ranging between 400 and $500 \mathrm{mg} / \mathrm{kg}$. Nickel, $\mathrm{Co}, \mathrm{Sb}$ and $\mathrm{Mn}$ concentrations were all below the levels recommended by WHO/FAO and NAFDAC for metals in foods and vegetables and are also within the normal range of metals in plants despite their remarkable variation in soil. Chromium concentrations were below the detection levels in most of studied plants with the exception of spring onions $(18.5 \mathrm{mg} / \mathrm{kg})$ grown in site $\mathrm{C}$ and in radish $(12 \mathrm{mg} / \mathrm{kg})$ grown in site A.

Table 2 - Statistical summary of physicochemical properties and extractable concentrations $(\mathrm{mg} / \mathrm{kg})$ of heavy metals for the investigated soil samples from Damour city $(\mathrm{n}=20)$.

\begin{tabular}{|c|c|c|c|c|c|}
\hline Parameter & Mean & Median & $\begin{array}{c}\text { Standard } \\
\text { deviation }\end{array}$ & Maximum & Minimum \\
\hline pH & 7.9 & 7.96 & 0.29 & 8.06 & 7.45 \\
\hline TOC (\%) & 2.8 & 2.65 & 1.16 & 6.29 & 1.52 \\
\hline Sand (\%) & 82 & 83 & 8.4 & 90 & 70 \\
\hline Silt (\%) & 12 & 12 & 7.1 & 12 & 0.8 \\
\hline Clay (\%) & 6 & 5 & 2.5 & 6 & 4.5 \\
\hline Zn ex & 18 & 11 & 19 & 72 & 1 \\
\hline Cu ex & 0.9 & 0.6 & 0.7 & 3.0 & 0.4 \\
\hline Ni ex & 3.9 & 3.5 & 1.4 & 6.7 & 2.1 \\
\hline Co ex & 15 & 16 & 5 & 26 & 1 \\
\hline Mn ex & 204 & 223 & 44 & 250 & 103 \\
\hline Fe ex & 11 & 9 & 9 & 44 & 3 \\
\hline Ba ex & 24 & 22 & 6 & 35 & 15 \\
\hline
\end{tabular}




\subsection{Metal interaction between soil and plants}

The correlation between concentrations of pseudototal and extractable heavy metals in soils, physicochemical soil properties (including $\mathrm{pH}$, total carbon and texture) and concentrations of heavy metals in plants was calculated. Significant positive correlation between pseudototal concentrations of soil samples and the concentrations of plant tissues, was observed only for Cu levels $\left(\mathrm{r}^{2}=77.47 \%\right)$. There was no correlation between the physicochemical soil properties ( $\mathrm{pH}, \mathrm{TOC}$, texture) and elemental concentrations. Regarding the soil samples a strong inter-correlation was observed between $\mathrm{Ni}, \mathrm{Cr}, \mathrm{Co}, \mathrm{Mn}$ and $\mathrm{Fe}$.

Based on average concentrations of the total study area, the acetic acid soil extraction provided a reasonable prediction of bioavailable $\mathrm{Ni}$ and $\mathrm{Ba}$, however, the bioavailability of $\mathrm{Zn}, \mathrm{Cu}$ and $\mathrm{Fe}$ was underestimated while the bioavailability of $\mathrm{Co}$ and $\mathrm{Mn}$ was overestimated (Fig. 3). A possible explanation for these differences might be that metal uptake by plants involves much more complex mechanisms compared to the potential of dilute acetic acid which only affects metals of specific soil phases, including the release of specifically adsorbed metals on mineral surfaces as well as the dissolution of carbonate minerals.

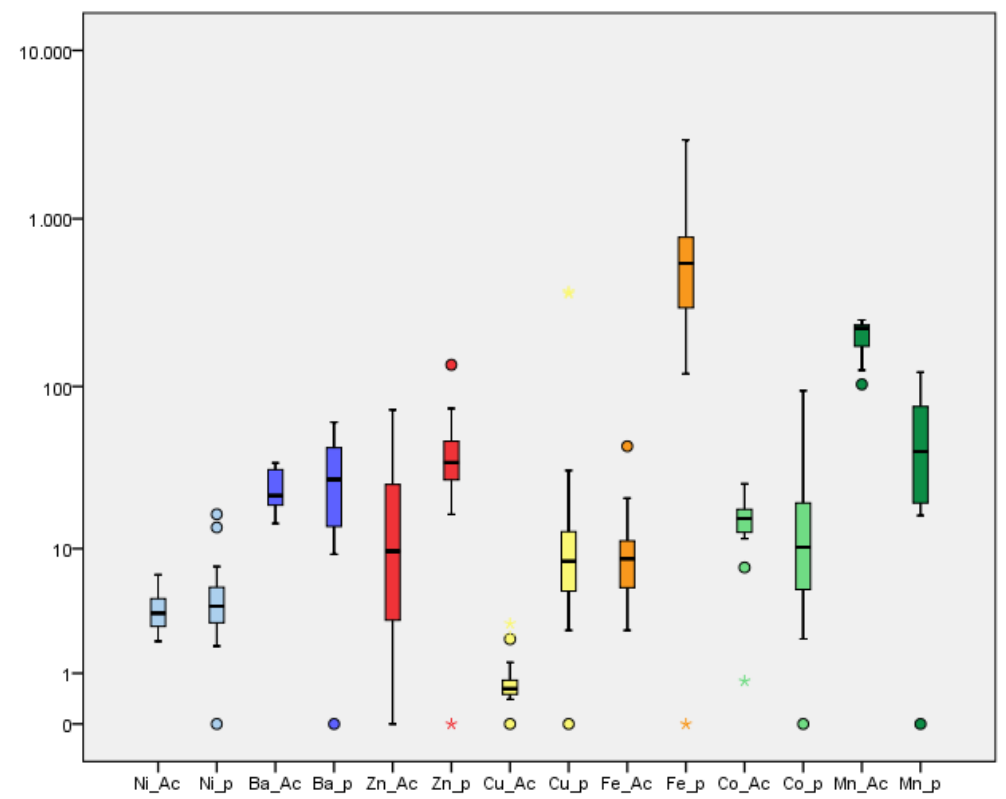

Figure 3 - Box plot comparison of elemental concentrations ( $\mathrm{mg} / \mathrm{kg}$ ) of heavy metals in acetic acid extracted soil (denoted by Ac) and plant tissues (denoted by p).

The three communal allotments within Damour areas (site A, site B and site C) were studied in this research in terms of land management and micronutrient concentrations in their produce since urban agriculture is a cosmopolitan upcoming trend. Based on a questionnaire that was distributed to the local managers it was found out that organic crop growing is practiced in all three of them without any application of chemical soil improvers, fertilizers and pesticides. Plants are irrigated with water originating from municipal boreholes. Previous land use varied from parking areas to unused urban space in Damour to horse stables and traditional cultivated parcels. In the first, the surface soil layer $(0-70 \mathrm{~cm})$ had been removed and new soil was brought in before starting the cultivation. All three allotments were used for communal agriculture for the past five years.

The average physicochemical topsoil properties from site $\mathrm{A}$, site $\mathrm{B}$ and site $\mathrm{C}$ were similar. The average $\mathrm{pH}$ of every site was 7.8 , the average TOC \% was 3.1 and the average sand, silt and clay 

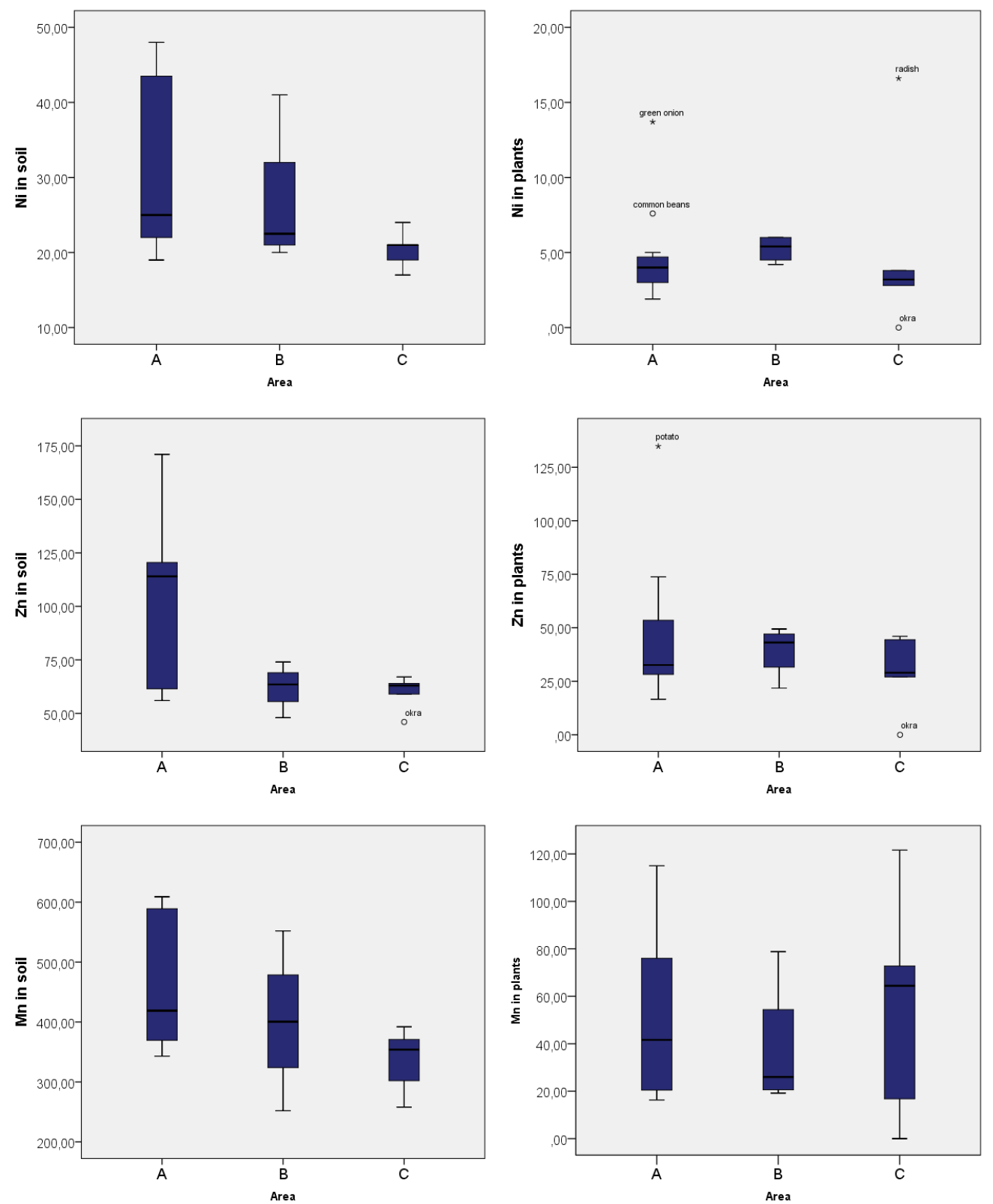

Figure 4 - Boxplot comparison of concentration ranges of $\mathrm{Ni}, \mathrm{Zn}$ and $\mathrm{Mn}$ in soil and plants in the three studied sites.

percentage were 82, 12 and 6 percent respectively. Significant variation of the median concentration values of the studied elements was only observed in site A but not in between sites B and C. Differences of elemental concentrations in soils were also well realized in the first site if compared to the others and this might be related to the previous use of the three studied areas (Fig. 4). Taking into account that different plant species were sampled in each allotment it is difficult to pinpoint any specific factors affecting micronutrient uptake by plants in the three areas. However, with the exception of few outliers elemental concentrations in plants are relatively uniform between the three sites when compared to their respective values in soil (Fig. 4). This observation is indicative of the ability of plant metabolic processes to balance the uptake of micronutrients according to their needs. 


\section{Conclusions}

Data on concentrations of heavy metals in soil and plants from urban agriculture areas in the city of Damour are presented for the first time. The geochemical signature of soil in three communal allotments was studied with respect to $\mathrm{Fe}, \mathrm{Mn}, \mathrm{Ba}, \mathrm{Zn}, \mathrm{Ni}, \mathrm{Cr}, \mathrm{Co}, \mathrm{Sb}, \mathrm{Pb}, \mathrm{Cu}$ and $\mathrm{Cd}$ and concentration levels in the edible parts of produced vegetables were measured. Heavy metal concentrations in plant tissues were below detection limit for $\mathrm{Pb}, \mathrm{Cr}$, and $\mathrm{As}$ and within normal ranges for healthy plant growth regarding the rest of the studied elements. Significant correlation was observed between pseudototal and acetic acid extractable concentrations in soil but there was no significant correlation between soils and plants, indicating that a more complex mechanism is controlling micronutrient uptake from soils to plants. Vegetable produce from the communal allotment of the first site contained higher concentrations of $\mathrm{Cu}, \mathrm{Co}, \mathrm{Mn}, \mathrm{Fe}$ and $\mathrm{Ba}$ compared to the other two communal agriculture areas. Further research is needed in order to determine the controlling factors of micronutrient uptake within the urban environment.

\section{Acknowledgments}

The authors would like to thank Dr. Ioannis Mitsis for his help and guidance during the plant tissue digestions. Special thanks are given to Dr. Adil Bakir for his involvement in chemical analysis of geochemical solutions at the analytical facilities of School of Earth \& Environmental Sciences, University of Portsmouth, UK.

\section{References}

Awofolu, O.R., 2005. A survey of trace metals in vegetation, soil, and lower animals along some selected major roads in Metropolitan City of Lagos, Environmental Monitoring and Assessment in Nigeria, 105, 431-447.

Argyraki, A. and Kelepertzis, E., 2014. Urban soil geochemistry in Athens, Greece: The importance of local geology in controlling the distribution of potentially harmful trace elements, Science of The Total Environment, 482-483, 366-377.

Bouyoucos, G.J., 1962. Hydrometer method improved for making particle size analysis of soils, Agronomy Journal, 54, 464-465.

Darwish, T. and Zurayk, R., 1997, 'Distribution and nature of red Mediterranean soils in Lebanon along altitudinal sequence', Catena, 28, 191-202.

Darwish, T., Haddad, T., Faour, G. and Aboudaher, M., 1999. Environmental changes due to land use changes in Tripoli area, North Lebanon. 6th International meeting on Soils with Mediterranean Type of Climate, Barcelona, Sopain, 4-9 July, 845-847.

Darwish, T.M., Jomaa, I., Awad, M. and Boumetri, R., 2008. Preliminary contamination hazard assessment of land resources in Central Bekaa Plain of Lebanon, Lebanese Science Journal, 9(2), 3-13.

Dubertret, L., 1955. Carte Géologique du Liban au 1/200,000, Note Explicative.

El Jisr, K., 2014. Polluant release and transfer register (PRTR) Lebanon, Final Project for UNEP, ECODIT, 2014.

El Moujabber, M., Atallah, T., Bou Samra, B., Fayssal, S., El-Chami, D., Mefleh, J. and Darwish, T., 2012. Seawater intrusion and crop response to salinity in coastal Lebanon, Lebanese Science Journal, 14(1), 2013.

FAO, 1973. Results of an airborne thermal infrared survey of the coast of Lebanon for marine sweet water springs. United nation, USA.

ISO 10390, 1994. Soil quality- determination of $\mathrm{pH}$.

Jaworowski. C., 1981. The effect of copper and fertilization with various forms of nitrogen on some physiological indices in maize, Acta Agrar. Silvistria, 20, 95 pp.

Kabata-Pendias, A. and Pendias, H., 2001. Trace Elements in Soils and Plants (third edition), CRS Press, Boca Raton, FI. 
Kakulu, S.E., 2003. Trace metal concentration in roadside surface soil and tree bark: a measurement of local atmospheric pollution in Abuja, Nigeria, Environmental Monitoring and Assessment, 89(3), 233-242.

Kelepertzis, E. and Argyraki, A., 2015. Geochemical associations for evaluating the availability of potentially harmful elements in urban soils: Lessons learnt from Athens, Greece, Applied Geochemistry, 59, 63-73.

Manta, D.S., Angelone, M., Bellanca, A., Neri, R. and Sprovieri, M., 2002. Heavy metals in urban soils: a case study from the city of Palermo (Silicy), Italy, Sci. Total Environ., 300, 229-43.

McLaughlin, M.J. and Singh, B.R., 1999. Cadmium in soil and plants: a global perspective. In: McLaughlin, M.J. and Singh, B.R., eds., Cadmium in soils and plants, Dordrecht, The Netherlands, Kluwer Academic Publishing, 13-21.

Opaluwa, O.Da., Aremu, M.Oa., Ogbo, L.Ob., Abiola, K.Ab., Odiba, I.Ec., Abubakar, M.Ma. and Nweze, N.Od., 2012. Heavy metal concentrations in soils, plant leaves and crops grown around dump sites in Lafia Metropolis, Nasarawa State, Nigeria, Advances in Applied Science Research, 3(2), 780-784.

Rodrigues, S., Urquhart, G., Hossack, I., Pereira, M.A., Duarte, A.C. and Davidson, C., 2009. The influence of anthropogenetic and natural geochemical factors of urban soil quality variability: a comparison between Glasgow, UK and Aveiro, Portugal, Environ. Chem. Lett., 7, 141-8.

Samad, F., 2000. Dynamics of Cd, Ni, and Cr in Four Lebanese Soils, M.Sc, Thesis, Faculty of Agricultural and Food Sciences, AUB, October 2000.

Sanlaville, P., 1977, Etude géomorphologique de la région littorale du Liban. Tome II, publication de l'université libanaise, section des 'études géographiques, Beyrouth-Liban, 402-859.

Srour, R., 2000. The Effect of Acid-Forming Fertilizers on the Mobility \& Uptake of Cd, Cr, and Ni by Radish Plants in Four Lebanese Soils, M.Sc. Thesis, Faculty of Agricultural and Food Sciences, AUB. May 2000.

Tahmasbian, I., Nasrazadani, A., Shoja, H. and Safari Sinegani, A.A., 2013. The effects of human activities and different land use on trace elements pollution in urban topsoil of Isfahan (Iran), Environ. Earth Sci., 71(4), 1551-1560.

US-EPA, 2002. Methods for the determination of total organic carbon (TOC) in soils and sediments, Report No. NCEA-C-1282, EMASC-001, Las Vegas, April 2002, United States Environmental Protection Agency.

Yao-Tsung, C., Zeng, Y.H. and Franz, Z., 2014. Evaluation of Phytoavailability of Heavy Metals to Chinese Cabbage (Brassica chinensis L.) in Rural Soils, The Scientific World Journal, 2014, Article ID 309396, 10 pp.

Warren, H.V., Delavault, R.E., Fletcher, K. and Wilks, E., 1970. Variation in the copper, zinc, lead and molybdenum content of some British Columbia vegetables. In: Trace Subst. environ. Health, Vol.4, Hemphill, D.D., Ed., University of Missouri Columbia, MO, 94.

Walley, C.D., 1998. The geology of Lebanon. A summary. Digital Documentation Center at AUB in collaboration with Al Mashriq of Høgskolen in Østfold, Norway, 980429 MB. 10 pp. 